UDC 577.112:616

\title{
EXPRESSION OF PHOSPHORIBOSYL PYROPHOSPHATE SYNTHETASE GENES IN U87 GLIOMA CELLS WITH ERN1 KNOCKDOWN: EFFECT OF HYPOXIA AND ENDOPLASMIC RETICULUM STRESS
}

\author{
O. H. MINCHENKO, I. A. GARMASH, O. V. KOVALEVSKA, \\ D. O. TSYMBAL, D. O. MINCHENKO
}

Palladin Institute of Biochemistry, National Academy of Sciences of Ukraine, Kyiv; e-mail: ominchenko@yahoo.com

\begin{abstract}
Activation of pentose phosphate pathway is an important factor of enhanced cell proliferation and tumor growth. Phosphoribosyl pyrophosphate synthetase (PRPS) is a key enzyme of this pathway and plays a central role in the synthesis of purines and pyrimidines. Hypoxia as well as ERN1 (from endoplasmic reticulum to nuclei-1) mediated endoplasmic reticulum stress response-signalling pathway is linked to the proliferation because the blockade of ERN1 suppresses tumor growth, including glioma. We studied the expression of different PRPS genes in glioma cells with ERN1 knockdown under hypoxic condition. It was shown that hypoxia decreases the expression of PRPS1 and PRPS2 genes in both types of glioma cells, being more pronounced in cells without ERN1 function, but PRPSAP1 and PRPSAP2 gene expressions are suppressed by hypoxia only in glioma cells with blockade of ERN1. Moreover, the blockade of endoribonuclease activity of ERN1 does not affect the expression of PRPS1 and PRPS2 as well as PPRS-associated protein genes in U87 glioma cells. At the same time, the induction of endoplasmic reticulum stress by tunicamycin in glioma cells with suppressed activity of ERN1 endoribonuclease decreases the expression level of PRPS1 and PRPS2 genes only. Results of this investigation clearly demonstrated that the expression of different genes encoding subunits of PRPS enzyme is affected by hypoxia in U87 glioma cells, but the effect of hypoxia is modified by suppression of endoplasmic reticulum stress signaling enzyme ERN1.
\end{abstract}

Key words: gene expression, pentose phosphate pathway, PRPS1, PRPS2, PRPSAP1, PRPSAP2, ERN1, hypoxia, glioma cells.

$\mathrm{M}$ alignant gliomas are highly aggressive tumors and are characterized by marked angiogenesis and extensive tumor cell invasion into the normal brain parenchyma, and to date there is no efficient treatment available. The very poor prognosis and the moderate efficacy of conventional clinical approaches therefore emphasize the need for new therapeutic strategies. Pentose phosphate pathway is necessary for purine metabolism as well as nucleotide biosynthesis and plays an important role in the regulation of proliferative processes and participates in endoplasmic reticulum stress, which is an important factor of tumor growth and many other diseases [1-5].

The endoplasmic reticulum is a key organelle in the cellular response to hypoxia and some chemicals which activate a complex set of signaling pathways named the unfolded protein response. This adaptive response is activated upon the accumulation of misfolded proteins in the endoplasmic reticulum and is mainly mediated by endoplasmic reticulum to nuclei-1 signaling enzyme (ERN1), also named inositol requiring enzyme-lalpha (IRE1 $\alpha$ ). ERN1 is the dominant sensor of the unfolded protein response to the accumulation of misfolded proteins and represents a key regulator of life and death processes [6-10]. As such, it participates in the early cellular response to the accumulation of misfolded proteins in the lumen of the endoplasmic reticulum [11, 12].

Two distinct catalytic domains of the bifunctional signaling enzyme ERN1 were identified: a serine/threonine kinase and endoribonuclease which contribute to ERN1 signalling. The ERN1-associated kinase activity autophosphorylates and dimerizes this enzyme, leading to the activation of its endoribonuclease domain, degradation of a specific subset of mRNA and initiation of the pre-XBP1 (X-box binding protein 1) mRNA splicing [10, 13]. Mature 
XBP1 mRNA splice variant encodes a transcription factor that has different C-terminus amino acid sequence and stimulates the expression of hundreds of unfolded protein response-specific genes [9, 13, 14]. However, XBP1s has additional functions, especially in the regulation of glucose homeostasis [15].

The endoplasmic reticulum stress is recognized as an important determinant of cancer and contributes to the expression profile of many regulatory genes resulting in proliferation and apoptosis [3, 12, 14]. Moreover, the malignant tumors use the endoplasmic reticulum stress and ischemia for activation of proliferation, because the endoplasmic reticulum stress response-signalling IRE-1 pathway is linked with the apoptosis as well as cell death processes and suppression of IRE-1 gene function significantly decreases the tumour growth [6, 16-18].

The ERN1 mediated endoplasmic reticulum stress response-signalling pathway is linked with the proliferation because the blockade of ERN1 suppresses tumour growth via specific changes in the cell transcriptome. Hypoxia as well as endoplasmic reticulum stress is responsible for regulation of numerous growth factors which control the cell proliferation and angiogenesis in malignant tumours, including glioma. Moreover, activation of pentose phosphate pathway is an important factor of enhanced cell proliferation and tumour growth [2, 4, 19, 20].

The pentose phosphate pathway plays an important part in the regulation of glycolysis and proliferation under different stress conditions and participates in control of apoptotic cell death [20]. Phosphoribosyl pyrophosphate synthetase plays a central role in tumor growth because it catalyzes the phosphoribozylation of ribose-5-phosphate to 5-phosphoribozyl-1-pyrophosphate, which is necessary for purine metabolism and nucleotide biosynthesis as a rate-limiting substrate for de novo and salvage purine synthesis $[2,4,19]$.

Human PRPS exists as heterogeneous aggregates composed of the $34 \mathrm{kDa}$ catalytic subunits (PRPSI or PRPS1 and PRPSII or PRPS2) and other 39 and $41 \mathrm{kDa}$ components designated PRPP synthetase-associated protein (PAP39 or PRPSAP1 and PAP41 or PRPSAP2). Recently it was shown that the non-homologous region of PRPS1 in Saccharomyces cerevisiae may contribute to the maintenance of cell wall integrity and cell viability [19]. Moreover, in multiple myeloma cells 5-aminoimidazole4 -carboxamide-1- $\beta$-riboside inhibited the uridine monophosphate synthetase activity and decreased the level of pyrimidine nucleotides and this pyrimidine starvation is responsible for induction of apoptosis in multiple myeloma cells [20]. Previously [21] it was shown that the blockade of endoplasmic reticulum stress sensor and signalling enzyme ERN1 in glioma cells resulted in dysregulation of the expression level of gene encoded different subunits of phosphoribosyl pyrophosphate synthetase: strong induction of PRPS1, PRPS2 and PRPSAP1 genes with more pronounced effect on PRPS1 gene and suppression of PRPSAP2 gene. However, the expression of phosphoribosyl pyrophosphate synthetase genes for different subunits of phosphoribosyl pyrophosphate synthetase in response to hypoxia and endoplasmic reticulum stress mediated by endoribonuclease of ERN1 and other signalling pathways is not studied yet.

The aim of this study was to investigate the expression of phosphoribosyl pyrophosphate synthetase genes in glioma cells with ERN1 signaling enzyme loss of function under hypoxic condition for developing a new conception concerning molecular mechanisms of malignant tumors progression in relation to endoplasmic reticulum stress and hypoxia.

\section{Materials and Methods}

Cell Lines and Culture Conditions. The glioma cell line U87 was obtained from ATCC (USA) and grown in high glucose (4.5 g/l) Dulbecco's modified Eagle's minimum essential medium (DMEM; Gibco, Invitrogen, USA) supplemented with glutamine (2 mM), 10\% fetal bovine serum (Equitech-Bio, Inc., USA), penicillin (100 units/ml; Gibco) and streptomycin $\left(0.1 \mathrm{mg} / \mathrm{ml}\right.$; Gibco) at $37^{\circ} \mathrm{C}$ in a $5 \% \mathrm{CO}_{2}$ incubator. In this work we used three sublines of this glioma cell line. One subline was obtained by selection of stable transfected clones with overexpression of pcDNA3.1 vector, which was used for creation of dominant-negative ERN1 constructs (dnERN1). This subline of glioma cells was used as control 1 in the study of hypoxia on the expression level of PRPS1, PRPS2, PRPSAP1 and PRPSAP2 genes and designated in this study as control glioma cells. The second subline was obtained by selection of stable transfected clones with overexpression of dnERN1 and suppressed both protein kinase and endoribonuclease activities of this bifunctional sensing and signaling enzyme of endoplasmic reticulum stress. These cells were obtained from prof. M. Moenner (France) $[16,17]$. The third subline was obtained by 
selection of stable transfected clones with expression of dominant-negative ERN1 endoribonuclease mutant constructs, it suppressed endoribonuclease activities of signaling enzyme ERN1 described previously [18].

The expression level of studied genes in these cells was compared with cells, transfected by vector (control 1), but the subline which overexpress dnERN1 was also used as control 2 for investigation of the effect of hypoxic condition on the expression level of PRPS genes under blockade of signaling enzyme ERN1 function. For creation of hypoxic condition, the culture plates were exposed in a special incubator with $3 \%$ oxygen, $5 \%$ carbon dioxide, and $92 \%$ nitrogen mix for $16 \mathrm{~h}$.

The blockade of functional activity of ERN1 in glioma cells that overexpress dnERN1 construct was previously analyzed by detection of XBP1 alternative splice variant (XBP1s), a key transcription factor in ERN1 signaling, and the level of ERN1 phosphorylated isoform in cells under endoplasmic reticulum stress induced by tunicamycin $(0.01 \mathrm{mg} / \mathrm{ml}$ for $2 \mathrm{~h})$ [22].

RNA isolation. Total RNA was extracted from glioma cells using Trisol reagent (Invitrogen, USA) as previously described [23]. RNA pellets were washed with $75 \%$ ethanol and dissolved in nucleasefree water. For additional purification RNA samples were precipitated with $95 \%$ ethanol and re-dissolved again in nuclease-free water.

Reverse transcription and quantitative PCR analysis. QuaniTect Reverse Transcription Kit (QIAGEN, Germany) was used for cDNA synthesis as described previously [24, 25]. The expression levels of PRPS1, PRPS2, PRPSAP1, and PRPSAP2 mRNA were measured in glioma cell line U87 and its sublines by real-time quantitative polymerase chain reaction using "Mx 3000P QPCR" (Stratagene, USA) and Absolute qPCR SYBRGreen Mix (Thermo Fisher Scientific, ABgene House, UK). Polymerase chain reaction was performed in triplicate.

For amplification of phosphoribosyl pyrophosphate synthetase 1 (PRPS1) cDNA we used the next primers: forward (5'-AAGAACGGAAGAAGGCCAAT- $3^{\prime}$ and reverse (5'-GACCGGAGAAGATTCCATGA-3') primers. The nucleotide sequences of these primers correspond to sequences 786-805 and 971-952 of human PRPS1 cDNA (GenBank accession number NM_002764). The size of amplified fragment is $186 \mathrm{bp}$.

Two other primers were used for real time RCR analysis of phosphoribosyl pyrophosphate syn- thetase 2 (PRPS2) cDNA: forward (5'-AAAACATTGCCGAGTGGAAG-3' and reverse (5'-TGACGACAACAGCCTCAAAG-3') primers. The nucleotide sequences of these primers correspond to sequences 613-632 and 957-948 of human PRPS2 cDNA (GenBank accession number NM_002765). The size of amplified fragment is $345 \mathrm{bp}$.

For amplification of phosphoribosyl pyrophosphate synthetase-associated protein 1 (PRPSAP1) cDNA we used the next primers: forward 5'-GTCCTATGCGGAGAGACTGC-3' and reverse 5'-TAGGCGCCTCTCTCTTTCAG-3'. These oligonucleotides correspond to sequences 1088-1107 and 1366-1347 of human PRPSAP1 cDNA (GenBank accession number NM_002766). The size of amplified fragment is $279 \mathrm{bp}$.

For amplification of phosphoribosyl pyrophosphate synthetase-associated protein 2 (PRPSAP2) cDNA we used the next primers: forward 5'-CACCCATGGTCAGAAGTGTG-3' and reverse 5'-TTAATCTTGGGGCACTGGAG-3'. These oligonucleotides correspond to sequences 894-913 and 1221-1202 of human PRPSAP2 cDNA (GenBank accession number NM_002767). The size of amplified fragment is $328 \mathrm{bp}$.

The amplification of $\beta$-actin (ACTB) cDNA was performed using forward - 5'-GGACTTCGAGCAAGAGATGG-3' and reverse - 5'-AGCACTGTGTTGGCGTACAG-3' primers. These primers nucleotide sequences correspond to 747-766 and 980-961 of human ACTB cDNA (GenBank accession number NM_001101). The size of amplified fragment is $234 \mathrm{bp}$. The expression of $\beta$-actin mRNA was used as control of analyzed RNA quantity. The primers were received from Sigma (USA).

An analysis of quantitative PCR was performed using special computer program Differential Expression Calculator and statistical analysis - according to Student's test using OriginPro 7.5 software. The values of PRPS1, PRPS2, PRPSAP1, and PRPSAP2 mRNA expressions were normalized to the expression of ACTB mRNA and represent as percent of control 1 (100\%). All values are expressed as mean \pm SEM from triplicate measurements performed in 4 independent experiments.

\section{Results and Discussion}

We studied the expression of four different genes which encoded phosphoribosyl pyrophosphate synthetase, which exists as heterotetramer and contains two catalytic subunits (PRPS1 and PRPS2) and 
two associated proteins (PRPSAP1 and PRPSAP2) in U87 glioma cells under hypoxia and under complete blockade of ERN1 signaling enzyme function as well as in cells with mutation in ERN1 endoribonuclease active center. As shown in Fig. 1 and 2, the expression level of both catalytic subunits of phosphoribosyl pyrophosphate synthetase did not change significantly in glioma U87 cells with blockade only endoribonuclease activity of ERN1; however, the knockdown of both enzymatic activities of this signaling enzyme of endoplasmic reticulum stress leads to up-regulation of PRPS1 and PRPS2 mRNA expressions $(P<0.05)$, being more significant for PRPS1 gene.

At the same time, the blockade of only endoribonuclease activity of ERN1 signaling enzyme did not change significantly the expression level of genes which encoded both associated proteins of phosphoribosyl pyrophosphate synthetase, but complete blockade of ERN1 signaling enzyme (both protein kinase and endoribonuclease activities) affects both PRPS1 and PRPS2 gene expressions in different ways (Fig. 3 and 4). Thus, ERN1 knockdown increases the expression level of PRPS1 gene $(P<0.05)$ and decreases that of PRPS2 gene $(P<0.05)$.

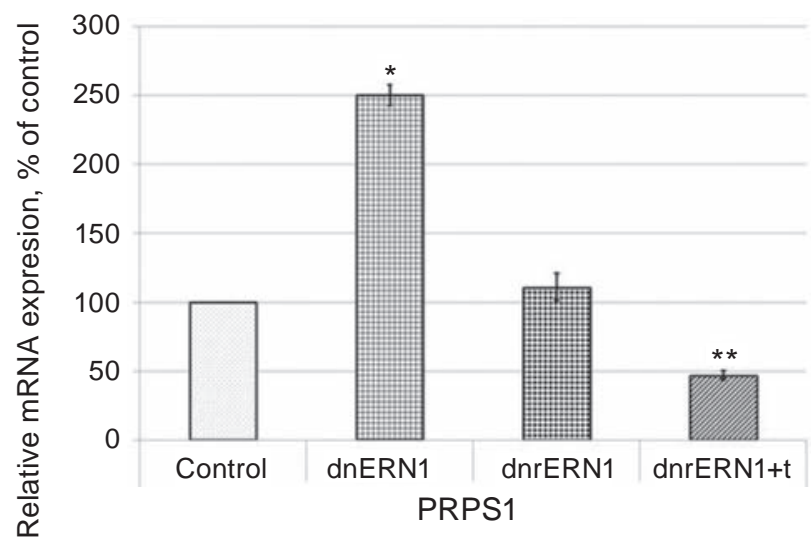

Fig. 1. Expression of phosphoribosyl pyrophosphate synthetase 1 (PRPS1) mRNA in glioma cell line U87 (Vector) and its subline with a deficiency of both enzymatic activities of the signaling enzyme ERN1 (dnERN1) or without endoribonuclease activity only (dnrERN1) measured by qPCR. dnrERN1+tdnrERN1 cells treated by tunicamycin $(0.01 \mathrm{mg} / \mathrm{ml}-$ 2 hrs). Values of PRPS1 mRNA expressions were normalized to $\beta$-actin $m R N A$ expression and represent as percent of control (100\%); $n=4 ; * P<0.05$ as compared to control; ${ }^{* *} \mathrm{P}<0.05$ as compared to dnrERN1
Moreover, we have shown that the induction of endoplasmic reticulum stress by tunicamycin in glioma cells with suppressed endoribonuclease activity of ERN1 signaling enzyme leads to a significant decrease (close to 2-fold; $P<0.05$ ) of both catalytic subunits of PRPS (Fig. 1 and 2). However, no significant changes were observed in the expression level of both genes which encoded PPRS associated proteins in these cells treated with tunicamycin (Fig. 3 and 4). At the same time, the expression of PRPSAP2 gene is decreased in glioma cells with suppressed ERN1 enzyme function.

It was also shown that exposure of U87 glioma cells to hypoxia leads to suppression of PRPS1 gene expression both in control glioma cells and cells with ERN1 knockdown $(P<0.05)$, but more robust effect of hypoxia was observed in glioma cells with ERN1 signaling enzyme function (Fig. 5). As shown in Fig. 6, the expression level of PRPS2 gene is also decreased both in control glioma cells and cells with ERN1 knockdown $(P<0.05)$, but suppression of ERN1 signaling enzyme function did not change significantly the effect of hypoxia on this gene expression.

At the same time, the expression of PRPSAP1 gene was resistant to hypoxia condition in control

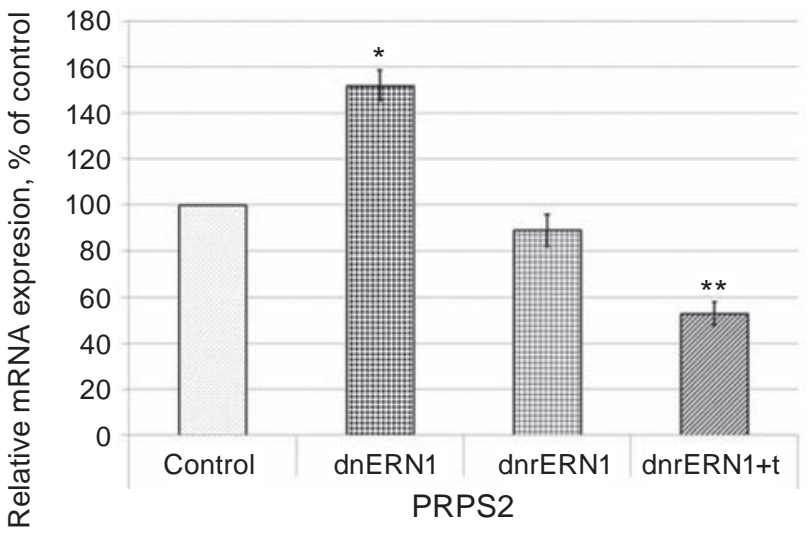

Fig. 2. Expression of phosphoribosyl pyrophosphate synthetase 2 (PRPS2) mRNA in glioma cell line U87 (Vector) and its subline with a deficiency of both enzymatic activities of the signaling enzyme ERN1 (dnERN1) or without endoribonuclease activity only (dnrERN1) measured by qPCR. dnrERN1+t dnrERN1 cells treated by tunicamycin $(0.01 \mathrm{mg} / \mathrm{ml}-$ 2 hrs). Values of PRPS2 mRNA expressions were normalized to $\beta$-actin $m R N A$ expression and represent as percent of control (100\%); $n=4 ; * P<0.05$ as compared to control; ** $P<0.05$ as compared to dnrERN1 


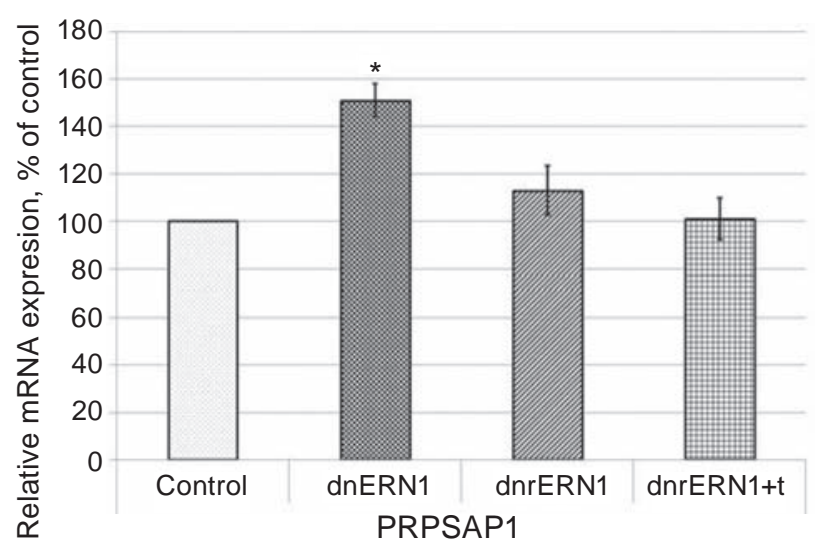

Fig. 3. Expression of phosphoribosyl pyrophosphate synthetase associated protein 1 (PRPSAP1) mRNA in glioma cell line U87 (Vector) and its subline with a deficiency of both enzymatic activities of the signaling enzyme ERN1 (dnERN1) or without endoribonuclease activity only (dnrERN1) measured by $q P C R$. dnrERN1+t - dnrERN1 cells treated by tunicamycin $(0.01 \mathrm{mg} / \mathrm{ml}-2 \mathrm{~h})$. Values of PRP$S A P 1$ mRNA expressions were normalized to $\beta$-actin mRNA expression and represent as percent of control (100\%); $n=4 ; * P<0.05$ as compared to control; ** $P<0.05$ as compared to dnrERN1

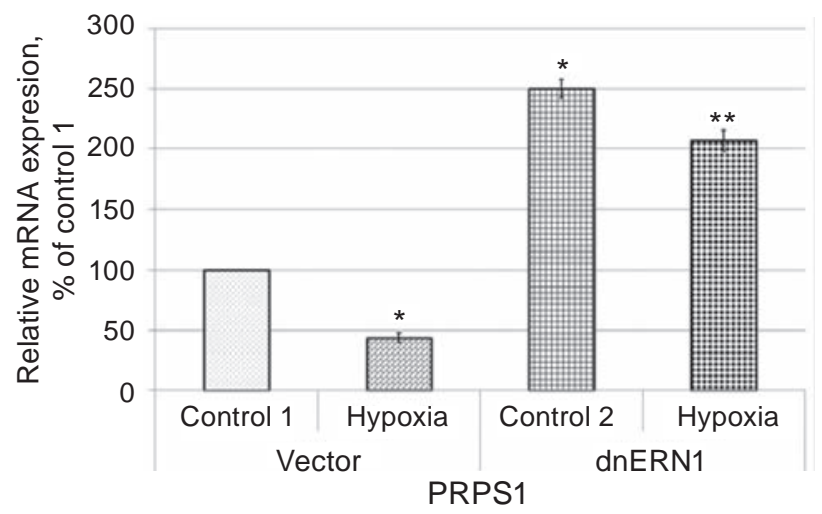

Fig. 5. The expression of phosphoribosyl pyrophosphate synthetase 1 (PRPS1) mRNA in glioma cell line U87 (Vector) and its subline with a deficiency of the signaling enzyme ERN1 (dnERN1): effect of hypoxia. Values of PRPS1 mRNA expressions were normalized to $\beta$-actin $m R N A$ expression and represent as percent of control (100\%); $n=4 ; * P<0.05$ as compared to control $1 ;{ }^{* *} P<0.05$ as compared to control 2.

glioma cells, but suppression of ERN1 signaling enzyme function modified the sensitivity of this gene expression to hypoxia (Fig. 7). Thus, the expression

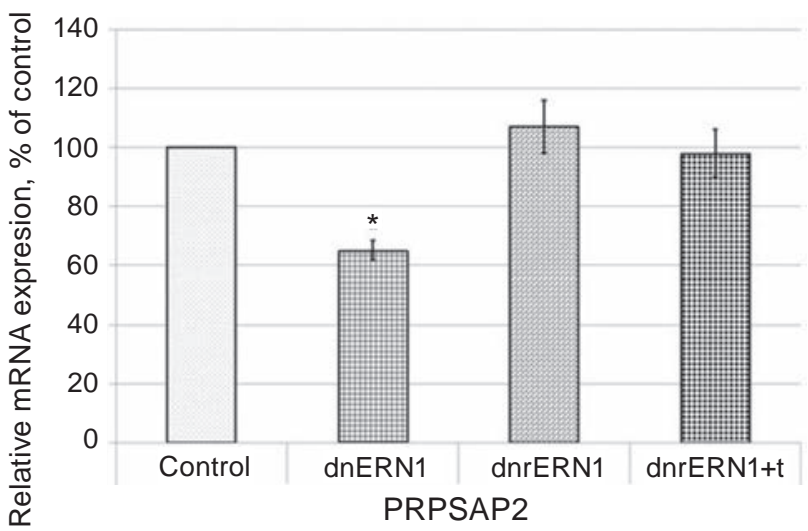

Fig. 4. Expression of phosphoribosyl pyrophosphate synthetase associated protein 2 (PRPSAP2) mRNA in glioma cell line U87 (Vector) and its subline with a deficiency of both enzymatic activities of the signaling enzyme ERN1 (dnERN1) or without endoribonuclease activity only (dnrERN1) measured by qPCR. dnrERN1+t - dnrERN1 cells treated by tunicamycin $(0.01 \mathrm{mg} / \mathrm{ml}-2 \mathrm{~h})$. Values of PRPSAP2 $m R N A$ expressions were normalized to $\beta$-actin $m R N A$ expression and represent as percent of control (100\%); $n=4 ; * P<0.05$ as compared to control; $* * P<0.05$ as compared to dnrERN1

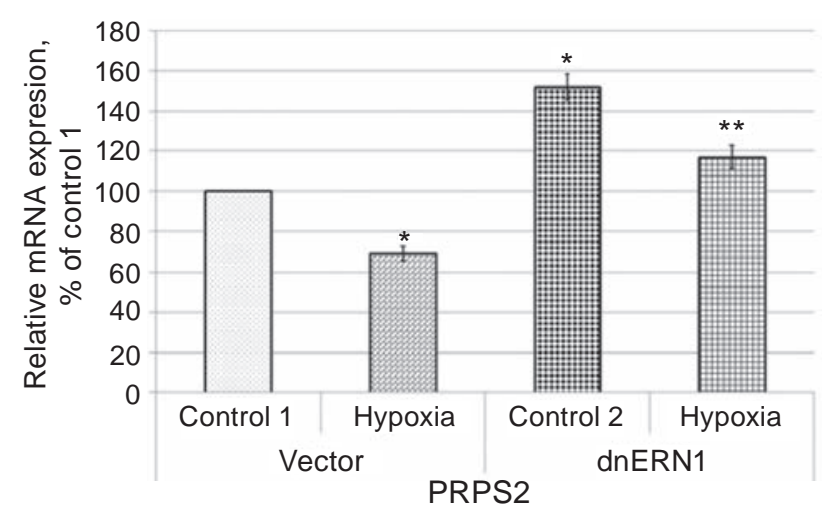

Fig. 6. Effect of hypoxia on the expression of phosphoribosyl pyrophosphate synthetase 2 (PRPS2) mRNA in glioma cell line U87 (Vector) and its subline with a deficiency of the signaling enzyme ERN1 (dnERN1) measured by qPCR. Values of PRPS2 $m R N A$ expressions were normalized to $\beta$-actin mRNA expression and represent as percent of control (100\%); $n=4$; ${ }^{*} P<0.05$ as compared to control 1; ** $P<0.05$ as compared to control 2

of PRPSAP1 gene in glioma cells with ERN1 loss of function is decreased $(P<0.05)$ under hypoxia condition. It was also found that PRPSAP2 gene expres- 
sion did not change significantly in control glioma cells, but in cells with ERN1 knockdown the expression of PRPSAP2 was increased under hypoxia $(P<0.05)$ (Fig. 8).

We have studied the expression of four different genes of phosphoribosyl pyrophosphate synthetase, because this enzyme contains two catalytic subunits and two associated subunits encoded by separate genes. Phosphoribosyl pyrophosphate synthetase enzyme is very important in the pentose phosphate pathway both in health and disease [26, 27]. Previously [21] it was shown that the blockade of endoplasmic reticulum stress sensor and signalling enzyme ERN1 in glioma cells resulted in dysregulation of the expression level of genes which encoded different subunits of phosphoribosyl pyrophosphate synthetase: strong induction of PRPS1, PRPS2 and PRPSAP1 genes with more pronounced effect on PRPS1 gene and suppression of PRPSAP2 gene. Thus, all genes encoding different subunits of phosphoribosyl pyrophosphate synthetase are responsible for endoplasmic reticulum stress, in particular its ERN1 signalling pathway; however, in diverse ways. This dysregulation of the expression of genes for different subunits of phosphoribosyl pyrophosphate synthetase, which is necessary for purine metabolism and nucleotide biosynthesis [27], possibly contribute to suppression of glioma cells proliferation

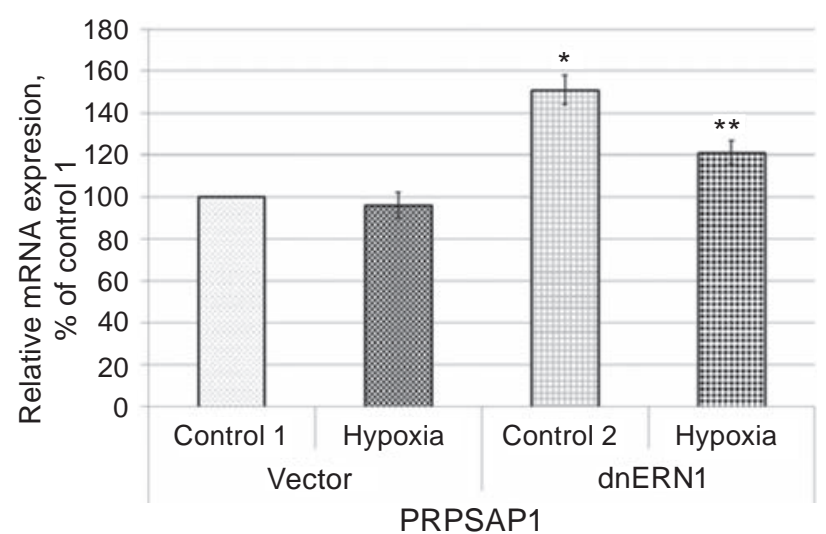

Fig. 7. The expression of phosphoribosyl pyrophosphate synthetase associated protein 1 (PRPSAP1) mRNA in glioma cell line U87 (Vector) and its subline with a deficiency of the signaling enzyme ERN1 (dnERN1): effect of hypoxia. Values of PRPSAP1 $m R N A$ expressions were normalized to $\beta$-actin $m R N A$ expression and represent as percent of control (100\%); $n=4 ; * P<0.05$ as compared to control 1; ${ }^{* *} P<0.05$ as compared to control 2 upon blockade of ERN1 gene function and glioma growth from these cells [16, 17].

Activation of pentose phosphate pathway is an important factor of enhanced cell proliferation and tumor growth, and phosphoribosyl pyrophosphate synthetase is a key enzyme of this pathway because it plays a central role in the synthesis of purines and pyrimidines. Moreover, the pentose phosphate pathway as well as endoplasmic reticulum stress is important in the regulation of glycolysis and proliferation during different stress conditions and participates in control of apoptotic cell death and cell viability $[19,20]$. Thus, the suppression of ERN1 gene function in glioma cells significantly decreases the tumor growth, and dysregulation of the expression of different genes encoding PRPS enzyme is in agreement with this data.

At the same time, we did not find some changes in the expression level of all studied genes of phosphoribosyl pyrophosphate synthetase in glioma cells after blockade of only endoribonuclease activity of ERN1 signaling enzyme. It is possible that endoribonuclease of ERN1 enzyme is not responsible for changes in the expression level of genes which encoded both catalytic subunits of phosphoribosyl pyrophosphate synthetase and its associated proteins, which we observed in glioma cells with complete blockade of both ERN1 enzymatic activities.

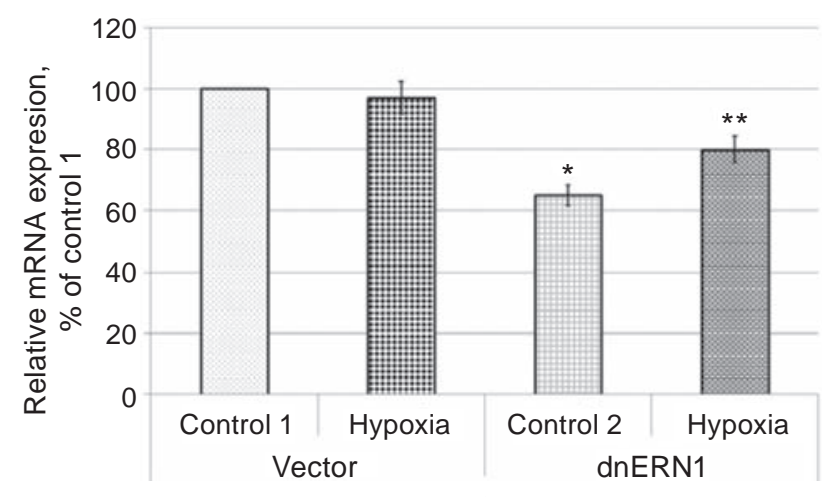

PRPSAP2

Fig. 8. Effect of hypoxia on the expression of phosphoribosyl pyrophosphate synthetase associated protein 2 (PRPSAP2) mRNA in glioma cell line U87 (Vector) and its subline with a deficiency of the signaling enzyme ERN1 (dnERN1). Values of PRPSAP2 mRNA expressions were normalized to $\beta$-actin $m R N A$ expression and represent as percent of control (100\%); $n=4 ; * P<0.05$ as compared to control 1; ** $P<0.05$ as compared to control 2 
Moreover, our results with induction of endoplasmic reticulum stress by tunicamycin in glioma cells without endoribonuclease activity of ERN1 signaling enzyme clearly demonstrate that both catalytic subunits are also regulated by other signaling pathways of endoplasmic reticulum stress or by protein kinase activity of ERN1. Thus, tunicamycininduced endoplasmic reticulum stress decreases the expression of PRPS1 and PRPS2 genes in glioma cells without endoribonuclease activity of ERN1, but blockade of kinase and endoribonuclease activities leads to up-regulation of the expression of both these gene expressions.

Moreover, we have shown that hypoxia condition also affects the expression of PRPS1 and PRPS2 genes in control U87 glioma cells and this data correlate with down-regulation of these gene expressions upon tunicamycin treatment, because hypoxia as well as tunicamycin is the inductor of endoplasmic reticulum stress. We have also found that hypoxic regulation of PRPS1 gene expression depends on ERN1 signaling enzyme function, because the effect of hypoxia was more pronounced in control glioma cells. At the same time, the expression of PRPSAP1 and PRPSAP2 genes was resistant to hypoxia condition in control glioma cells but decreased (PRPSAP1) or increased (PRPSAP2) in glioma cells with ERN1 loss of function. Thus, the expression of these genes which encoded both phosphoribosyl pyrophosphate synthetase associated proteins in U87 glioma cells also depend on ERN1 function. These results are consistent with the data of other investigation, where the dependence of different gene expressions under hypoxic as well as nutrient deprivation conditions on ERN1 signaling enzyme function [22-25] was shown. Thus, blockade of ERN1signaling enzyme can enhance, reduce or eliminate hypoxic regulation of gene expression.

It is interesting to note that the mechanism of hypoxic regulation is realized usually through transcription factor HIF, but there are many different factors which control the level of this transcription factor in low oxygen conditions as well as in malignant tumors under normoxic conditions [25, 28-34]. Hypoxia-inducible mir-210, transglutaminase, deltacatenin, c-Myc as well as ATR (ataxia telangiectasia and Rad3 related protein), which is a member of the phosphoinositide 3-kinase-related kinases family, are among them.

Thus, the expression of genes encoding different subunits of phosphoribosyl pyrophosphate synthetase enzyme, which plays a central role in the synthesis of nucleotides and controls tumor growth, is dependent on ERN1 signaling enzyme function as well as hypoxic condition.

Results of this investigation clearly demonstrated that hypoxia decreases the expression of PRPS1 and PRPS2 genes in both types of glioma cells, but PRPSAP1 and PRPSAP2 - only in glioma cells with endoplasmic reticulum stress signaling enzyme ERN1 knockdown and that the effect of hypoxia is modified by suppression of ERN1. Moreover, blockade of endoribonuclease activity of ERN1 does not affect the expression of PRPS1 and PRPS2 as well as PPRS-associated protein genes in U87 glioma cells. At the same time, the induction of endoplasmic reticulum stress by tunicamycin in glioma cells with suppressed activity of ERN1 endoribonuclease decreases the expression level of PRPS1 and PRPS2 genes only. These data show that the expression of PRPS1 and PRPS2 genes is controlled by protein kinase of ERN1 or possibly other signaling pathways of endoplasmic reticulum stress.

\section{ЕКСПРЕСІЯ ГЕНІВ ФОСФОРИБОЗИЛ- ПІРОФОСФАТСИНТЕТАЗИ У КЛІТИНАХ ГЛІОМИ ЛІНІї U87 3 ВИКЛЮЧЕНИМ ERN1: ВПЛИВ ГІПОКСІї ТА СТРЕСУ ЕНДОПЛАЗМАТИЧНОГО РЕТИКУЛУМА}
О. Г. Мінченко, Я. А. Гармаш,
О. В. Ковалевська, Д. О. Цимбал,
Д. О. Мінченко
Інститут біохімії ім. О. В. Палладіна
НАН України, Київ; e-mail: ominchenko@yahoo.com

Активація пентозо-фосфатного шляху $\epsilon$ важливим чинником посилення проліферативних процесів i росту пухлин. Фосфорибозилпірофосфатсинтетаза (PRPS) $є$ ключовим ензимом цього шляху і відіграє центральну роль у синтезі пуринів та піримідинів. Як гіпоксія, так і опосередкований ERN1 сигнальний шлях стресу ендоплазматичного peтикулума пов'язані з процесами проліферації клітин, оскільки блокада ERN1 пригнічує ріст пухлин, включаючи гліому. Ми досліджували експресію різних генів PRPS у клітинах гліоми з пригніченою функцією ERN1 за гіпоксії. Пока- 
зано, що гіпоксія зменшує рівень експресії генів PRPS1 та PRPS2 в обох типах клітин гліоми, але в більшій мірі у клітинах 3 пригніченою функцією ERN1, хоча рівень експресії генів PRPSAP1 та PRPSAP2 знижувався за гіпоксії лише у клітинах гліоми з виключеною функцією сигнального ензиму ERN1. Більше того, блокада ендорибонуклеазної активності ERN1 не призводила до істотних змін в експресії генів як PRPS1 i PRPS2, так і PRPSAP1 та PRPSAP2 у клітинах гліоми лінії U87. У той же час індукція стресу ендоплазматичного ретикулума тунікаміцином у клітинах гліоми із пригніченою ендорибонуклеазною активністю ERN1 знижувала лише рівень експресії генів PRPS1 і PRPS2. Результати цього дослідження вказують на те, що гіпоксія впливає на рівень експресії генів різних субодиниць ензиму PRPS у клітинах гліоми лінії U87 і що ефект гіпоксії змінюється за виключення ERN1, сигнального ензиму стресу ендоплазматичного ретикулума.

К лючов і слов а: експресія генів, пентозо-фосфатний шлях, PRPS1, PRPS2, PRPSAP1, PRPSAP2, ERN1, гіпоксія, клітини гліоми.

\section{ЭКСПРЕССИЯ ГЕНОВ ФОСФОРИБОЗИЛ- ПИРОФОСФАТСИНТЕТАЗЫ \\ В КЛЕТКАХ ГЛИОМЫ ЛИНИИ U87 С ВЫКЛЮЧЕННЫМ ERN1: ВЛИЯНИЕ ГИПОКСИИ И СТРЕССА ЭНДОПЛАЗМАТИЧЕСКОГО РЕТИКУЛУМА}

\section{А. Г. Минченко, Я. А. Гармаш, \\ О. В. Ковалевская, Д. О. Цымбал, Д. А. Минченко}

\author{
Институт биохимии им. А. В. Палладина \\ НАН Украины, Киев; \\ e-mail: ominchenko@yahoo.com
}

Активация пентозо-фосфатного пути является важным фактором усиления пролиферативных процессов и роста опухолей. Фосфорибозилпирофосфатсинтетаза (PRPS) является ключевым энзимом этого пути и играет центральную роль в синтезе пуринов и пиримидинов. Как гипоксия, так и опосредованный ERN1 сигнальный путь стресса эндоплазматического ретикулума связаны с процессами пролиферации клеток, поскольку блокада ERN1 угнета- ет рост опухолей, включая глиому. Мы исследовали экспрессию различных генов PRPS в клетках глиомы с угнетенной функцией ERN1 при гипоксии. Показано, что гипоксия снижает уровень экспрессии генов PRPS1 и PRPS2 в обоих типах клеток глиомы, но в большей степени в клетках с угнетенной функцией ERN1, хотя уровень экспрессии генов PRPSAP1 и PRPSAP2 снижался при гипоксии лишь в клетках глиомы с выключенной функцией сигнального энзима ERN1. Более того, блокада эндорибонуклеазной активности ERN1 не приводила к существенным изменениям в экспрессии генов как PRPS1 и PRPS2, так и PRPSAP1 и PRPSAP2 в клетках глиомы линии U87. В то же время индукция стресса эндоплазматического ретикулума туникамицином в клетках глиомы с угнетенной эндорибонуклеазной активностью ERN1 снижала лишь уровень экспрессии генов PRPS1 и PRPS2. Результаты этого исследования указывают на то, что гипоксия влияет на уровень экспрессии генов различных субъединиц энзима PRPS в клетках глиомы линии U87 и, что эффект гипоксии изменяется при выключении ERN1, сигнального энзима стресса эндоплазматического ретикулума.

К лючевы е слов а: экспрессия генов, пентозо-фосфатный путь, PRPS1, PRPS2, PRPSAP1, PRPSAP2, ERN1, гипоксия, клетки глиомы.

\section{References}

1. Wang S., Kaufman R. J. The impact of the unfolded protein response on human disease. J. Cell Biol. 2012;197(7):857-867.

2. Iizasa T. Increased activity of PRPP synthetase. Nihon Rinsho. 2008;66(4):694-698.

3. Moenner M., Pluquet O., Bouchecareilh M., Chevet E. Integrated endoplasmic reticulum stress responses in cancer. Cancer Res. 2007;67(22):10631-10634.

4. Mannava S., Grachtchouk V., Wheeler L. J., Im M., Zhuang D., Slavina E. G., Mathews C. K., Shewach D. S., Nikiforov M. A. Direct role of nucleotide metabolism in C-MYC-dependent proliferation of melanoma cells. Cell Cycle. 2008;7(15):2392-2400.

5. de Brouwer A. P., van Bokhoven H., Nabuurs S. B., Arts W. F., Christodoulou J., Duley J. PRPS1 mutations: four distinct syndromes and potential treatment. Am. J. Hum. Genet. 2010;86(4):506518. 
6. Bi M., Naczki C., Koritzinsky M., Fels D., Blais J., Hu N., Harding H., Novoa I., Varia M., Raleigh J., Scheuner D., Kaufman R. J., Bell J., Ron D., Wouters B. G., Koumenis C. ER stressregulated translation increases tolerance to extreme hypoxia and promotes tumor growth. EMBO J. 2005;24(19):3470-3481.

7. Fels D. R., Koumenis C. The PERK/eIF2a/ATF4 module of the UPR in hypoxia resistance and tumor growth. Cancer Biol. Ther. 2006;5(7):723728.

8. Romero-Ramirez L., Cao H., Nelson D., Hammond E., Lee A. H., Yoshida H., Mori K., Glimcher L. H., Denko N. C., Giaccia A. J., Le Q-T., Koong A. C. XBP1 is essential for survival under hypoxic conditions and is required for tumor growth. Cancer Res. 2004;64:59435947.

9. Acosta-Alvear D., Zhou Y., Blais A, Tsikitis M., Lents N. H., Arias C., Lennon C. J., Kluger Y., Dynlacht D. D. XBP1 controls diverse cell typeand condition-specific transcriptional regulatory networks. Mol. Cell. 2007;27(1):53-66.

10. Schröder M. Endoplasmic reticulum stress responses. Cell Mol. Life Sci. 2008;65(6):862894.

11. Lin J. H., Walter P., Yen T. S. Endoplasmic reticulum stress in disease pathogenesis. Annu. Rev. Pathol. 2008;3:399-425.

12. Marciniak S. J., Ron D. Endoplasmic reticulum stress signaling in disease. Physiol. Rev. 2006; 86(4): 1133-1149.

13. Hollien J., Lin J. H., Li H., Stevens N., Walter P., Weissman J. S. Regulated Ire1-dependent decay of messenger RNAs in mammalian cells. J. Cell Biol. 2009;186(3):323-331.

14. Aragón T., van Anken E., Pincus D., Serafimova I. M., Korennykh A. V., Rubio C. A., Walter P. Messenger RNA targeting to endoplasmic reticulum stress signalling sites. Nature. 2009;457(7230):736-740.

15. Lee S. K., Kim Y. S. Phosphorylation of eIF2 $\alpha$ attenuates statin-induced apoptosis by inhibiting the stabilization and translocation of p53 to the mitochondria. Int. J. Oncol. 2013;42(3):810-816.

16. Drogat B., Auguste P., Nguyen D. T., Bouchecareilh M., Pineau R., Nalbantoglu J., Kaufman R. J., Chevet E., Bikfalvi A., Moenner M. IRE1 signaling is essential for ischemia-induced vascular endothelial growth factor-A expression and contributes to angiogenesis and tumor growth in vivo. Cancer Res. 2007;67(14):6700-6707.

17. Auf G, Jabouille A, Guérit S, Pineau R, Delugin M, Bouchecareilh M, Magnin N, Favereaux A, Maitre M, Gaiser T, von Deimling A, Czabanka M, Vajkoczy P, Chevet E, Bikfalvi A, Moenner M. A shift from an angiogenic to invasive phenotype induced in malignant glioma by inhibition of the unfolded protein response sensor IRE1. Proc. Natl. Acad. Sci. USA. 2010;107(35):15553-15558.

18. Auf G., Jabouille A., Delugin M., Guérit S., Pineau R., North S., Platonova N., Maitre M., Favereaux A., Seno M., Bikfalvi A., Minchenko D., Minchenko O., Moenner M. High epiregulin expression in human U87 glioma cells relies on IRE1 $\alpha$ and promotes autocrine growth through EGF receptor. BMC Cancer 2013;13(1):597.

19. Fridman A., Saha A., Chan A., Casteel D. E., Pilz R. B., Boss G. R. Cell cycle regulation of purine synthesis by phosphoribosyl pyrophosphate and inorganic phosphate. Biochem. J. 2013;454(1):91-99.

20. Bardeleben C., Sharma S., Reeve J. R., Bassilian S., Frost P., Hoang B., Shi Y., Lichtenstein A. Metabolomics identifies pyrimidine starvation as the mechanism of 5-aminoimidazole-4-carboxamide-1- $\beta$-ribosideinduced apoptosis in multiple myeloma cells. Mol. Cancer Ther. 2013;12(7):1310-1321.

21. Minchenko D. O., Garmash I. A., Bashta Y. M., Kustkova G. S., Zalesna Y. D., Bikfalvi A., Minchenko O. H. ERN1 dependent expression of phosphoribosyl pyrophosphate synthetase genes in U87 glioma cells: effect of glucose or glutamine deprivation. Int. J. Genomic Med. 2013;1(1):104.

22. Minchenko D. O., Kubajchuk K. I., Ratushna O. O., Komisarenko S. V., Minchenko O. H. The effect of hypoxia and ischemic condition on the expression of VEGF genes in glioma U87 cells is dependent from ERN1 knockdown. Adv. Biol. Chem. 2012;2(2):198-206.

23. Minchenko D. O., Karbovskyi L. L., Danilovskyi S. V., Kharkova A. P., Minchenko O. H. Expression of casein kinase genes in glioma cell line U87: effect of hypoxia and glucose or glutamine deprivation. Nat. Sci. 2012;4(1):38-46.

24. Minchenko D. O., Karbovskyi L. L., Danilovskyi S. V., Moenner M., Minchenko O. H. 
Effect of hypoxia and glutamine or glucose deprivation on the expression of retinoblastoma and retinoblastoma-related genes in ERN1 knockdown glioma U87 cell line. Am. J. Mol. Biol. 2012;2(1):21-31.

25. Minchenko D. O., Kharkova A. P., Hubenia O. V., Minchenko O. H. Insulin receptor, IRS1, IRS2, INSIG1, INSIG2, RRA D, and BAIAP2 gene expressions in glioma U87 cells with ERN1 loss of function: effect of hypoxia and glutamine or glucose deprivation. Endocr. Regul. 2013;47(1):15-26.

26. Wamelink M. M., Struys E. A., Jakobs C. The biochemistry, metabolism and inherited defects of the pentose phosphate pathway: a review. J. Inherit. Metab. Dis. 2008;31(6):703-717.

27. Berry G. T. The unexplored potential of the pentose phosphate pathway in health and disease. J. Inherit. Metab. Dis. 2008;31(6):661.

28. Huang X., Ding L., Bennewith K. L., Tong R. T., Welford S. M., Ang K. K., Story M., Le Q. T., Giaccia A. J. Hypoxia-inducible mir-210 regulates normoxic gene expression involved in tumor initiation. Mol. Cell. 2009;35:856-867.

29. Kumar S., Mehta K. Tissue transglutaminase constitutively activates HIF- $1 \alpha$ promoter and nuclear factor- $\mathrm{\kappa B}$ via a non-canonical pathway. PLoS One. 2012;7(11):e49321.
30. He Y., Kim H., Ryu T., Kang Y., Kim J. A., Kim B. H., Lee J. H., Kang K., Lu Q., Kim K. $\delta$-catenin overexpression promotes angiogenic potential of CWR22Rv-1 prostate cancer cells via HIF-1 $\alpha$ and VEGF. FEBS Lett. 2013;587(2):193199.

31. Erpolat O. P., Gocun P. U., Akmansu M., Ozgun G., Akyol G. Hypoxia-related molecules HIF-1 $\alpha$, CA9, and osteopontin : Predictors of survival in patients with high-grade glioma. Strahlenther Onkol. 2013;189(2):147-154.

32. Chen C., Cai S., Wang G., Cao X., Yang X., Luo X., Feng Y., Hu J. c-Myc enhances colon cancer cell-mediated angiogenesis through the regulation of HIF-1 $\alpha$. Biochem. Biophys. Res. Commun. 2013;430(2):505-511.

33. Azar R., Lasfargues C., Bousquet C., Pyronnet S. Contribution of HIF-1 $\alpha$ in 4E-BP1 gene expression. Mol. Cancer Res. 2013;11(1):54-61.

34. Fallone F., Britton S., Nieto L., Salles B., Muller C. ATR controls cellular adaptation to hypoxia through positive regulation of hypoxiainducible factor 1 (HIF-1) expression. Oncogene. 2013;32(37):4387-4396.

Received 24.03.2014 